\title{
PENINGKATAN KEKERASAN DAN KETAHANAN KOROSI BIOMATERIAL METALIK JENIS STAINLESS STEEL 316L DAN Ti-6AI-4V MENGGUNAKAN TEKNIK NITRIDASI ION
}

\author{
Sudjatmoko, Wirjoadi, Lely Susita R.M., Bambang Siswanto \\ Pusat Teknologi Akselerator dan Proses Bahan - BATAN \\ Jl. Babarsari Kotak Pos 6101 Ykbb, Yogyakarta 55281 \\ e-mail : sd_moko@yahoo.co.id
}

Diterima 29 April 2011, diterima dalam bentuk perbaikan 15 Juni 2011, disetujui 24 Juni 2011

\begin{abstract}
ABSTRAK
PENINGKATAN KEKERASAN DAN KETAHANAN KOROSI BIOMATERIAL METALIK JENIS STAINLESS STEEL 316L DAN Ti-6AI-4V MENGGUNAKAN TEKNIK NITRIDASI ION. Telah dilakukan nitridasi ion pada cuplikan biomaterial metalik jenis stainless steel 316L dan Ti-6Al-4V untuk meningkatkan sifat kekerasan dan ketahanan korosinya. Proses nitridasi ion dilakukan dengan variasi parameter suhu nitridasi, tekanan gas nitrogen dan waktu nitridasi untuk mendapatkan kekerasan yang tinggi dan ketahanan korosi yang sangat baik. Kekerasan optimum cuplikan stainless steel $316 \mathrm{~L}$ diperoleh pada suhu nitridasi $500^{\circ} \mathrm{C}$, waktu nitridasi 3 jam dan tekanan gas nitrogen 1,6 mbar; sedangkan untuk cuplikan Ti-6Al-4V diperoleh pada suhu nitridasi $500^{\circ} \mathrm{C}$, waktu nitridasi 3 jam dan tekanan gas nitrogen 1,8 mbar. Pengamatan struktur-mikro dan komposisi unsur dilakukan menggunakan SEMEDAX, dan penentuan struktur fase lapisan nitrida yang terbentuk pada permukaan cuplikan dilakukan dengan teknik XRD. Lapisan nitrida yang terbentuk pada cuplikan stainless steel 316L terdiri dari struktur fase $\mathrm{FeN}, \mathrm{Fe}_{2} \mathrm{~N}$ dan $\mathrm{Fe}_{4} \mathrm{~N}$, dan pada cuplikan Ti-6Al-4V terdiri dari struktur fase $\mathrm{Ti}_{2} \mathrm{~N}$, TiAIN, $\mathrm{Ti}_{3} \mathrm{AIN}$ dan $\mathrm{Ti}_{3} \mathrm{Al}_{2} \mathrm{~N}_{2}$. Nitrida tersebut memiliki sifat sangat keras atau mempunyai ketahanan aus sangat baik. Ketahanan korosi cuplikan yang ternitridasi diuji menggunakan alat uji korosi dengan mengukur besarnya arus korosi. Ketahanan korosi optimum diperoleh pada suhu nitridasi $450^{\circ} \mathrm{C}$.
\end{abstract}

Kata kunci : Kekerasan, ketahanan korosi, biomaterial, nitridasi ion, struktur-mikro, struktur fase.

\begin{abstract}
INCREASING OF THE HARDNESS AND THE CORROSION RESISTANCE OF METALLIC BIOMATERIALS TYPE 316L STAINLESS STEEL AND Ti-6Al-4V BY USING ION NITRIDING TECHNIQUE. Ion nitriding has been carried out on samples of metallic biomaterials type 316L stainless steel and Ti-6Al-4V to improve the properties of hardness and corrosion resistance. Ion nitriding process carried out by varying parameters of nitriding temperature, pressure of nitrogen gas and nitriding time in order to get the high hardness and a very good corrosion resistance. Microhardness of the samples was measured using a microhardness tester, the optimum hardness of 316L stainless steel samples was obtained at the nitriding temperature of $500^{\circ} \mathrm{C}$, the nitriding time of 3 hours and the nitrogen gas pressure of 1.6 mbar, while for Ti-6Al-4V samples was obtained at the nitriding temperature of $500^{\circ} \mathrm{C}$, the nitriding time of 3 hours and the nitrogen gas pressure of 1.8 mbar. Observation of the micro-structure and composition of elements were performed using SEM-EDAX, and the determination of phase structure of nitride layer formed on the surface of samples was done by XRD techniques. The nitride layer which formed on 316L stainless steel samples consists of the phase structures of $\mathrm{FeN}_{2} \mathrm{Fe}_{2} \mathrm{~N}$ and $\mathrm{Fe}_{4} \mathrm{~N}$, and Ti-6Al-4V samples consists of the phase structures of $\mathrm{Ti}_{2} \mathrm{~N}, \mathrm{TiAIN}, \mathrm{Ti}_{3} \mathrm{AIN}$ and $\mathrm{Ti}_{3} \mathrm{Al}_{2} \mathrm{~N}_{2}$. These nitrides have the high hardness or a very good wear resistance. Corrosion resistance of the nitrided 316L stainless steel and Ti-6Al-4V samples was tested using a corrosion tester by measuring the corrosion currents. Optimum corrosion resistance was obtained at the nitriding temperature of $450^{\circ} \mathrm{C}$.
\end{abstract}

Keywords: Hardness, corrosion resistance, biomaterial, ion nitriding, microstructure, phase structure.

\section{PENDAHULUAN}

alam bidang kedokteran, sebuah prostetik atau piranti cangkok ortopedik adalah tulang atau sambungan buatan yang menggantikan bagian tubuh yang hilang, dan biasanya digunakan untuk menggantikan bagian yang hilang oleh cedera (trauma) atau hilang dari lahir (bawaan) atau untuk melengkapi bagian-bagian tubuh yang cacat. Biomaterial tersebut telah banyak digunakan untuk memperbaiki atau menggantikan fungsi suatu 
sistem otot-kerangka tubuh manusia yang sakit atau rusak, seperti tulang, tulang sendi dan gigi ${ }^{(1)}$. Pada saat ini permintaan prostetik tersebut semakin meningkat setiap tahunnya di seluruh dunia, hal ini terjadi karena jumlah pasien yang memerlukan dan menerima pencangkokan prostetik untuk memperbaiki cacat atau kerusakan tulang rangka dan penyembuhan penyakit juga meningkat. Di seluruh dunia telah terjadi permintaan atau kebutuhan yang sangat besar dilakukannya pencangkokan tulang pinggang dan persendian lutut. Suatu laporan studi tentang penjualan prostetik atau piranti cangkok ortopedik seluruh dunia pada tahun 2003 telah mencapai USD 8,7 milyar dan diperkirakan akan meningkat setiap tahunnya dengan laju pertumbuhan sekitar $12,5 \%$ dan mencapai sekitar USD 17,9 milyar pada tahun 2009 ini. ${ }^{(2)}$ Saat ini di Amerika Serikat dan Eropa lebih dari 600.000 pencangkokan tulang pinggang dan persendian lutut dilakukan setiap tahunnya dengan kecenderungan terus bertambah jumlahnya pada tahun-tahun mendatang. ${ }^{(3)}$ Pada tahun 2003 pasar prostetik atau piranti cangkok ortopedik diseluruh Eropa diperkirakan mencapai USD 402,4 juta dan pada tahun 2010 diharapkan berkembang menjadi USD 536,2 juta; ${ }^{(4)}$ sedangkan di Amerika Serikat telah dilakukan pencangkokan sekitar 138.000 sambungan tulang pinggang dan 245.000 persendian tulang lutut pada tahun 1996. ${ }^{(5,6)}$ Keperluan pencangkokan prostetik tersebut meningkat sekitar $9,8 \%$ per tahun dan menjadi sekitar USD 23 milyar pada tahun $2012^{(7)}$.

Meskipun kebutuhan piranti cangkok ortopedik meningkat seperti tersebut di atas, akan tetapi dijumpai adanya permasalahan ketahanan aus dan korosi, khususnya pada piranti cangkok ortopedik berbasis biomaterial metalik. Apabila suatu piranti ortopedik yang terbuat dari biometalik dicangkokkan ke dalam tubuh manusia, maka piranti tersebut berada dalam cairan jaringan ekstraseluler (extracellular tissue fluid) yang bersifat korosif. Permukaan metal dari piranti ortopedik tersebut akan mengalami pelarutan material secara elektrokimia pada kelajuan tertentu sebagai akibat terjadinya interaksi dengan lingkungan di sekitarnya. Di dalam tubuh manusia, lingkungan tersebut dapat terdiri dari air, campuran organik kompleks, oksigen terlarut, sodium, khlorida, bikarbonat, kalium, kalsium, magnesium, fosfat, asam amino, protein, plasma, cairan getah bening dan lainnya. Korosi mulai terjadi ketika cairan tubuh bereaksi dengan material piranti ortopedik menghasilkan partikel-partikel halus serupa dengan partikel-partikel kecil akibat proses keausan. Korosi tersebut tidak hanya memperlemah piranti ortopedik yang dicangkokkan, tetapi partikel-partikel halus yang dihasilkan dapat tetap tertinggal di dalam jaringan di sekitar cangkokan dan dapat mengakibatkan kegagalan pencangkokan atau yang lebih parah dapat merusak tulang. Oleh karena itu biomaterial tersebut harus biocompatible dan tidak menyebabkan terjadinya perangsangan atau penolakan oleh jaringan tubuh, dan harus nontoxic dan noncarcinogenic, serta tahan terhadap keausan untuk dapat menahan beban secara berulang dalam lingkungan tubuh yang agresif.

Pada pemakaian cangkok piranti ortopedik jangka panjang juga akan terjadi proses keausan, dan menghasilkan partikel-partikel kecil dan ion-ion metal (khususnya titanium, khrom, kobalt dan nikel) yang diekskresikan diduga menjadi penyebab terjadinya tumor ganas fibrous histiocytoma. ${ }^{\left({ }^{8}\right)}$ Di dalam tubuh pasien partikel-partikel kecil akibat keausan dapat menyebabkan terjadinya reaksi yang mengakibatkan peradangan jaringan tubuh. Jika terjadi peradangan berat pada jaringan tubuh atau peradangan terjadi secara kontinyu dalam jangka panjang, maka peradangan tersebut dapat mengakibatkan kegagalan pencangkokan.

Ada tiga jenis paduan yang sering digunakan untuk piranti ortopedik, yaitu stainless steel jenis $316 \mathrm{~L}$, paduan titanium Ti-6Al-4V dan paduan berbasis kobalt-khrom yang bersifat biocompatible. Secara luas telah diketahui bahwa keausan dan korosi biomaterial berbasis metal atau biometalik adalah salah satu aspek penting dalam operasi pencangkokan tulang..$^{(9,10,11)}$ Berdasarkan suatu kajian yang pernah dilakukan memperlihatkan bahwa sebagian besar, dan bahkan hingga sekitar 90\%, kegagalan pencangkokan piranti cangkok ortopedik atau prostetik berbasis metal, khususnya austenitic stainless steel jenis 316L, disebabkan oleh serangan korosi akibat berinteraksi dengan cairan tubuh dan terjadi keausan karena menahan beban gesekan dalam tulang sendi. (1) Oleh karena itu diperlukan suatu metode untuk memperbaiki sifat-sifat mekanik material, khususnya untuk meningkatkan ketahanan korosi dan ketahanan ausnya dengan melakukan modifikasi permukaan biomaterial. Dalam makalah ini dibahas pemanfaatan teknik nitridasi ion dengan tujuan untuk meningkatkan kekerasan atau ketahanan aus dan ketahanan korosi dari biomaterial SS 316L dan Ti-6Al-4V. Nilai kekerasan dari lapisan tipis nitrida metal yang terbentuk pada permukaan cuplikan, kekerasannya ditentukan menggunakan 
Peningkatan Kekerasan dan Ketahanan Korosi Biomaterial Metalik Jenis Stainless Steel 316L dan Ti-6Al-4V Menggunakan Teknik Nitridasi Ion (Sudjatmoko, Wirjoadi, Lely Susita RM., Bambang Siswanto)

micro-hardness tester, pengukuran keausan dikerjakan menggunakan alat uji-aus, penentuan ketahanan korosi dilakukan menggunakan potensiostat PGS-201T, sedangkan struktur-mikro dan komposisi kimia serta struktur fasenya diamati menggunakan SEM-EDAX dan XRD. 


\section{METODOLOGI}

\section{Bahan}

Bahan yang digunakan dalam proses nitridasi ion adalah biomaterial berbasis besi berupa stainless steel austenitik jenis 316L dengan kemurnian (\% berat): Fe-69\%, Cr-18\%, Ni-10\%, Mo-3\% dan paduan Ti-6Al-4V: Ti$90 \%, \mathrm{Al}-6 \%$, V-4\%; sedangkan bahan-bahan yang digunakan dalam pembuatan larutan Hanks untuk uji korosi terdiri dari $\mathrm{NaCl}, \mathrm{CaCl}_{2}, \mathrm{KCl}, \mathrm{NaHCO}_{3}$, glukosa, $\mathrm{NaH}_{2} \mathrm{PO}_{4}, \mathrm{MgCl}_{2} \cdot 6 \mathrm{H}_{2} \mathrm{O}, \mathrm{Na}_{2} \mathrm{HPO}_{4} \cdot 2 \mathrm{H}_{2} \mathrm{O}$, dan $\mathrm{MgSO}_{4} .7 \mathrm{H}_{2} \mathrm{O}$ produksi PT Merck yang memiliki tingkat kemurnian $99,5 \%$.

\section{Alat}

Peralatan yang digunakan dalam penelitian ini terdiri dari: microhardness-tester merk MATSUZAWA MMTX7, alat uji korosi potensiostat PGS-201T, SEM-EDAX merk Jeol JSM-636 OLA, dan difraktometer sinar-X (XRD) tipe Simadzu XRD-6000 menggunakan sumber radiasi CuK $\alpha$ dengan panjang gelombang 1,54056Å.

\section{Tata Kerja}

\section{Preparasi cuplikan}

Bahan yang digunakan untuk cuplikan berupa stainless steel austenitik jenis $316 \mathrm{~L}$ dan paduan Ti-6Al-4V dipotong-potong dengan ukuran $1,0 \mathrm{~cm} \times 1,0 \mathrm{~cm}$ dan tebal 2,0 $\mathrm{mm}$. Potongan cuplikan dalam bentuk keping tersebut dihaluskan permukaannya menggunakan kertas ampelas, selanjutnya dipoles menggunakan pasta intan dan digosok dengan kain beludru sampai dihasilkan permukaan yang halus dan mengkilap. Untuk menghilangkan kotoran pada permukaan cuplikan dilakukan pencucian menggunakan alkohol dan kemudian dimasukkan ke dalam pembersih ultrasonik.

\section{Proses nitridasi ion}

Nitridasi ion dilakukan menggunakan peralatan nitridasi ion yang terdiri dari bejana vakum terbuat dari logam dilengkapi dengan sistem vakum, sistem masukan gas nitrogen, sistem tegangan tinggi DC $300-1.200$ volt dan regulator suhu. Untuk mendapatkan nilai kekerasan atau ketahanan aus optimum dan ketahanan korosi yang masih baik, maka dilakukan variasi suhu nitridasi, tekanan gas nitrogen dan waktu nitridasi ion. Pada penelitian ini suhu nitridasi ion divariasi pada kisaran $350,400,450,500$ dan $550{ }^{\circ} \mathrm{C}$; sedangkan tekanan gas nitrogen divariasi untuk nilai 1,2; 1,4; 1,6;1,8; 2,0 dan 2,4 mbar; dan variasi waktu nitridasi ion 1, 2, 3, 4 dan 5 jam.

\section{Karakterisasi cuplikan}

Pengujian kekerasan lapisan tipis nitrida besi hasil nitridasi ion dilakukan menggunakan alat uji Knoop (Knoop Microhardness Tester) dan angka kekerasan Knoop (Knoop Hardness Number $=$ KHN) diperoleh dari persamaan,

$$
K H N=14,23 P / L^{2}
$$

dimana $K H N$ adalah angka kekerasan mikro, $P$ adalah beban yang digunakan (gf) dan $L$ adalah panjang diagonal yang lebih panjang (mm). Nilai kekerasan tersebut berkaitan dengan ketahanan aus, dimana keausan merupakan peristiwa gesekan dan pelepasan partikel-partikel metal dari permukaannya yang disebabkan oleh metal atau logam lainnya, bahan non metal, cairan atau gas yang bergerak. Nilai ketahanan aus berbading terbalik dengan kekerasan, maka ketahanan ausnya semakin baik jika nilai kekerasannya semakin besar. Ketahanan aus ditentukan berdasarkan pada laju material yang aus atau jumlah material yang terauskan (massa, volume atau tebal) per satuan jarak luncur atau waktu pengausan.

Ketahanan korosi cuplikan ditentukan menggunakan alat uji korosi potensiostat PGS-201T untuk mengukur besarnya arus korosi $I_{\text {kor. }}$. Arus korosi ini menentukan sifat permukaan bahan, untuk bahan yang lebih tahan terhadap korosi maka arus korosinya kecil, yang berarti jumlah ion-ion positif yang mengalir setiap detik akan lebih sedikit dibandingkan dengan bahan yang tak tahan terhadap korosi. Besarnya laju korosi sebagai fungsi dari arus korosi (ampere $/ \mathrm{m}^{2}$ ), yaitu besarnya arus listrik yang mengalir dari anode menuju ke katode atau 
sebaliknya, rapat jenis bahan dan luas cuplikan; dan besarnya laju korosi cuplikan lapisan nitrida besi dapat ditentukan dengan persamaan:

$$
\text { Laju korosi (mpy) }=\left(0,13 \times I_{\text {kor }} \times E W\right) /(A . d)
$$

dengan 0,13 adalah faktor konversi metrik dan waktu, $I_{\text {kor }}$ adalah intensitas arus korosi $\left(\mu \mathrm{A} / \mathrm{m}^{2}\right), E W$ adalah berat ekivalen (g/ekivalen), $A$ adalah luas cuplikan $\left(\mathrm{cm}^{2}\right)$ dan $d$ adalah densitas $\left(\mathrm{g} / \mathrm{cm}^{3}\right)$.

Untuk mengetahui struktur mikro dan komposisi unsur permukaan cuplikan dilakukan analisis dengan menggunakan SEM (Scanning Electron Microscope) dan EDAX (Energy Dispersive Analysis X-Ray). Sedangkan untuk mengetahui struktur kristal dari lapisan tipis nitrida besi dilakukan pengujian dengan XRD $(X-$ ray Diffraction). Dengan informasi puncak difraktogram pada sudut $2 \theta$, jarak antar bidang $d$ dihitung dengan menggunakan rumus Bragg: $\lambda=2 d \sin \theta$. Nilai $d$ digunakan untuk menentukan orientasi dari bidang ( $h k l)$ dengan membandingkan tabel HANAWAL, JCPDS (Joint Committee on Powder Diffraction Standards).

\section{HASIL DAN PEMBAHASAN}

Dalam penelitian yang dilakukan ini dipilih cuplikan biomaterial bersifat biocompatible yang tidak akan memperoleh tanggap yang merugikan atau bersifat penolakan dari tubuh, dan harus nontoxic dan noncarcinogenic. Selain itu biomaterial harus memiliki sifat-sifat fisika dan mekanik yang baik untuk dapat berfungsi sebagai prostetik atau piranti cangkok ortopedik; dan untuk penggunaan praktis harus dapat dibentuk secara mudah dalam berbagai bentuk, biayanya relatif murah dan tersedia dengan mudah. Dengan pertimbangan tersebut cuplikan biomaterial yang digunakan adalah austenitic stainless steels jenis SS 316L dan Ti-6Al-4V. Biomaterial SS 316L dan Ti-6Al-4V tersebut adalah biomaterial berbasis metalik yang mempunyai sifat mekanik yang lebih kuat dibandingkan dengan biomaterial non metalik. Proses perlakuan permukaan bahan (surface treatment) dilakukan dengan teknik nitridasi ion karena dapat menghasilkan lapisan tipis nitrida metal, khususnya nitrida besi dan nitrida titanium yang sangat keras atau mempunyai sifat ketahanan aus sangat tinggi dan juga mempunyai ketahanan korosi yang baik; serta biaya operasionalnya relatif murah jika dibandingkan dengan teknik perlakuaan permukaan bahan lainnya seperti nitridasi gas dan lainnya.

\section{Karakterisasi Nilai Kekerasan dan Ketahanan Aus Cuplikan}

Nitrida metal yang terbentuk dari unsur-unsur tertentu seperti $\mathrm{Fe}, \mathrm{Ti}, \mathrm{Cr}, \mathrm{Al}$, Mo dan $\mathrm{V}$ pada proses nitridasi ion mempunyai sifat sangat istimewa, yaitu stabil secara kimia dan termal, sering memiliki sifat konduktor listrik dan termal yang baik, dan terutama mempunyai sifat sangat keras. Dalam proses nitridasi ion tersebut, parameter tekanan gas nitrogen, suhu nitridasi dan waktu nitridasi sangat berpengaruh terhadap peningkatan kekerasan cuplikan. Gambar 1 dan 2 masing-masing menampilkan grafik nilai kekerasan cuplikan SS 316L dan Ti-6Al-4V hasil proses nitridasi ion sebagai fungsi waktu nitridasi ion, pada suhu nitridasi $500{ }^{\circ} \mathrm{C}$, tekanan gas nitrogen 1,6 mbar dan 1,8 mbar. Dalam proses nitridasi ion, ketebalan lapisan senyawa nitrida besi dan nitrida titanium bergantung pada suhu nitridasi ion dan juga waktu nitridasi ion, ketebalannya akan meningkat dengan naiknya suhu nitridasi ion atau bertambahnya waktu nitridasi ion. Untuk waktu nitridasi ion yang pendek, nilai kekerasan cuplikan rendah karena lapisan senyawa nitrida besi dan nitrida titanium yang terbentuk masih sangat tipis. Ketika waktu nitridasi ion diperpanjang maka kandungan nitrogen dalam menjadi besar, dan ketebalan lapisan senyawa nitrida besi dan nitrida titanium bertambah besar dan mencapai optimum pada waktu nitridasi ion 3 jam. Jika waktu nitridasi ion diperpanjang lagi akan terjadi kejenuhan kandungan nitrogen dalam plasma untuk membentuk senyawa nitrida besi dan nitrida titanium, sehingga nilai kekerasan cuplikan menurun.

Berdasarkan hasil karakterisasi kekerasan cuplikan tersebut diperoleh bahwa nilai kekerasan optimum dari cuplikan SS 316L adalah sekitar $245 \mathrm{KHN}$ yang diperoleh pada tekanan gas nitrogen 1,6 mbar, suhu nitridasi ion $500{ }^{\circ} \mathrm{C}$ dan waktu nitridasi ion 3 jam. Jika nilai kekerasan cuplikan SS $316 \mathrm{~L}$ tersebut dibandingkan dengan nilai kekerasan cuplikan SS 316 L standar $180 \mathrm{KHN}$, maka terjadi peningkatan nilai kekerasan sekitar $136 \%$. Oliveira dkk..$^{(12)}$ dan Borgioli dkk. ${ }^{(13)}$ melaporkan bahwa nilai kekerasan stainless steel austenitik AISI 316L hasil nitridasi ion dipengaruhi oleh suhu nitridasi, dan nilai kekerasan optimumnya juga diperoleh pada suhu nitridasi $500{ }^{\circ} \mathrm{C}$. Pada cuplikan Ti-6Al-4V, kekerasan optimumnya dari hasil proses nitridasi ion adalah $675 \mathrm{KHN}$ yang diperoleh 
pada tekanan gas nitrogen $1,8 \mathrm{mbar}$, suhu nitridasi ion $500{ }^{\circ} \mathrm{C}$ dan waktu nitridasi ion 3 jam. Nilai kekerasan tersebut meningkat sebesar sekitar $240 \%$ terhadap kekerasan standar $281 \mathrm{KHN}$.

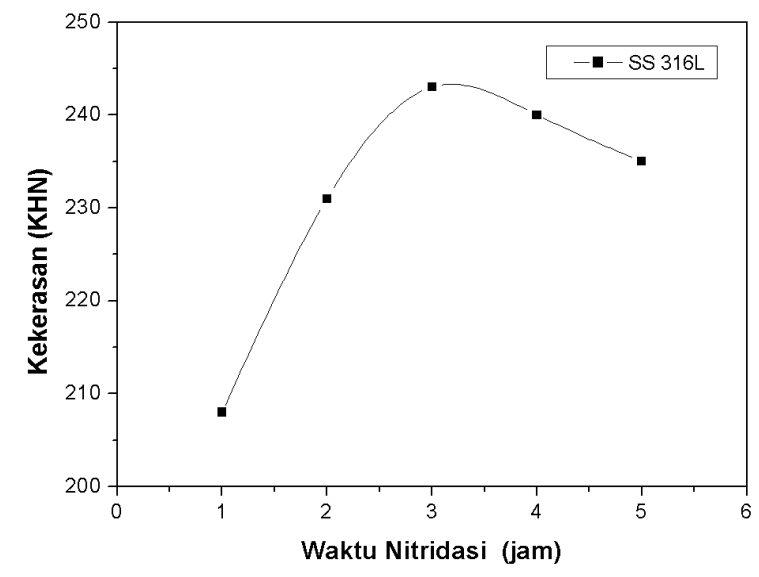

Gambar 1. Grafik nilai kekerasan cuplikan SS $316 \mathrm{~L}$ hasil proses nitridasi ion untuk variasi waktu nitridasi ion, pada suhu nitridasi ion $500^{\circ} \mathrm{C}$ dan tekanan gas nitrogen 1,6 mbar.

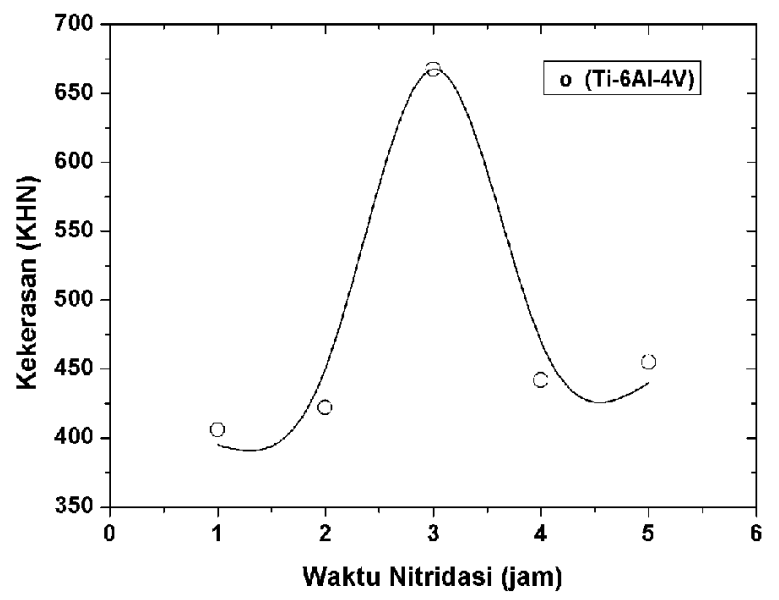

Gambar 2. Grafik nilai kekerasan cuplikan Ti-6Al-4V hasil proses nitridasi ion untuk variasi waktu nitridasi ion, pada suhu nitridasi ion $500^{\circ} \mathrm{C}$ dan tekanan gas nitrogen 1,8 mbar.

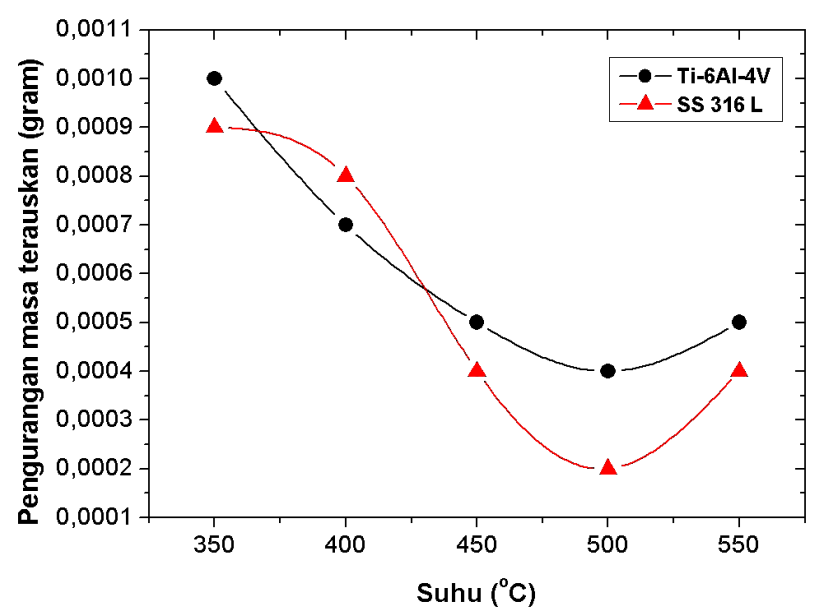


Gambar 3. Grafik keausan cuplikan SS 316L dan Ti-6Al-4V sesudah proses nitridasi ion untuk variasi suhu nitridasi ion, pada waktu nitridasi ion 3 jam dan tekanan gas nitrogen 1,6 mbar untuk cuplikan SS 316L dan 1,8 mbar untuk cuplikan Ti-6Al-4V.

Pada Gambar 3 ditampilkan grafik keausan cuplikan SS 316L dan Ti-6AI-4V sesudah proses nitridasi ion untuk variasi suhu nitridasi ion, pada waktu nitridasi ion 3 jam dan tekanan gas nitrogen 1,6 mbar untuk cuplikan SS 316L dan 1,8 mbar untuk cuplikan Ti-6Al-4V. Keausan merupakan peristiwa gesekan dan pelepasan partikel-partikel metal dari permukaannya yang disebabkan oleh metal atau logam lainnya, bahan non metal, cairan atau gas yang bergerak. Nilai ketahanan aus berbading terbalik dengan kekerasan, maka ketahanan ausnya semakin baik jika nilai kekerasannya semakin besar. Dalam penelitian ini ketahanan aus ditentukan berdasarkan pada laju material yang aus atau jumlah material yang terauskan, massa per satuan waktu pengausan. Berat beban pengaus adalah 301,10 gram dan waktu pengausan selama 15 menit. Berdasarkan Gambar 3 dapat diketahui bahwa ketahanan aus optimum cuplikan SS 316L juga dihasilkan pada nitridasi ion dengan suhu nitridasi $500{ }^{\circ} \mathrm{C}$, tekanan gas nitrogen 1,6 mbar dan waktu nitridasi 3 jam; sedangkan ketahanan aus optimum cuplikan Ti-6Al-4V diperoleh pada nitridasi ion dengan suhu nitridasi $500{ }^{\circ} \mathrm{C}$, tekanan gas nitrogen 1,8 mbar dan waktu nitridasi 3 jam. Ketahanan aus cuplikan SS 316L sesudah proses nitridasi ion meningkat sebesar $600 \%$, sedangkan untuk cuplikan Ti-6Al-4V meningkat sekitar 375\% jika dibandingkan dengan cuplikan standar.

\section{Karakterisasi Struktur-mikro dan Komposisi Kimia}

Dalam penelitian ini juga dilakukan pengamatan struktur-mikro dan komposisi kimia menggunakan teknik SEM-EDAX, terutama untuk mengetahui kandungan unsur nitrogen pada permukaan cuplikan setelah proses nitridasi ion. Pada Gambar 4 ditampilkan mikrograf SEM-EDAX dari cuplikan SS 316L setelah proses nitridasi ion pada suhu nitridasi $500{ }^{\circ} \mathrm{C}$, waktu nitridasi 3 jam dan tekanan gas nitrogen 1,6 mbar. Berdasarkan analisis komposisi kimia diperoleh bahwa cuplikan selain mempunyai kandungan unsur $\mathrm{Fe} 56,46 \%$ atom, $\mathrm{Cr} 16,06 \%$ atom, $\mathrm{Ni} 7,49 \%$ atom dan Mo 1,19\% atom, juga terdapat kandungan N 18,79\% atom yang berasal dari proses nitridasi ion. Sedangkan Gambar 5 menampilkan tampang lintang mikrograf SEM-EDAX dari cuplikan SS $316 \mathrm{~L}$ setelah nitridasi ion pada suhu nitridasi $500^{\circ} \mathrm{C}$, waktu nitridasi 3 jam dan tekanan gas nitrogen 1,6 mbar. Berdasarkan 

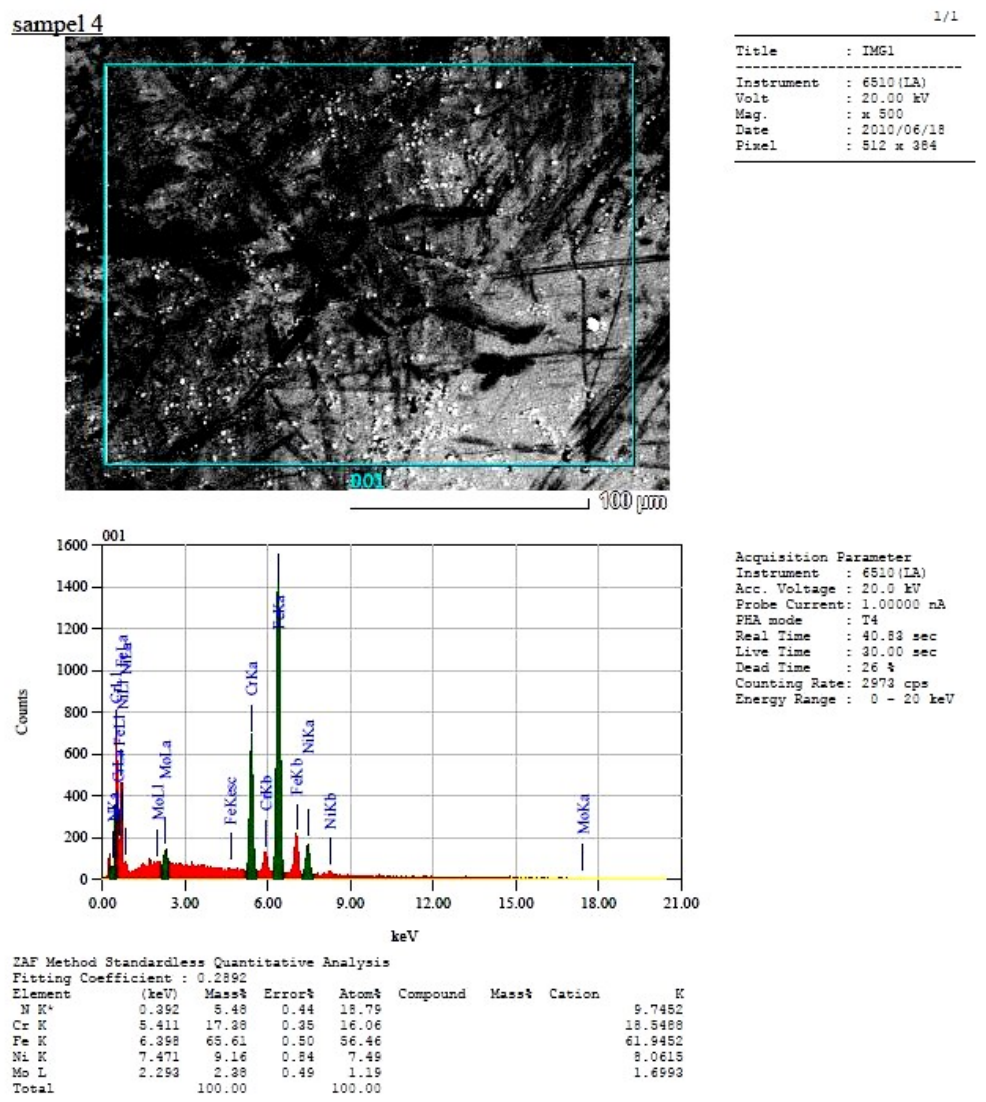

Gambar 4. Mikrograf SEM-EDAX dari cuplikan SS $316 \mathrm{~L}$ setelah nitridasi ion pada suhu nitridasi $500{ }^{\circ} \mathrm{C}$, waktu nitridasi 3 jam dan tekanan gas nitrogen 1,6 mbar.

Gambar 5 terlihat lapisan senyawa nitrida besi berwarna putih yang mengandung unsur nitrogen $29,48 \%$ atom dengan ketebalan tertentu, bergantung pada suhu nitridasi atau waktu nitridasi. Dalam proses nitridasi ion, nitrogen saat difusi ke dalam permukaan cuplikan akan berinteraksi dengan metal, khususnya besi membentuk lapisan senyawa nitrida besi FeN yang mempunyai sifat sangat keras atau mempunyai ketahanan aus yang tinggi. Untuk mengetahui struktur fase lapisan senyawa nitrida besi yang terbentuk, $\mathrm{Fe}_{2-3} \mathrm{~N}$ atau $\mathrm{Fe}_{4} \mathrm{~N}$ dan lainnya dapat ditentukan menggunakan teknik XRD. 


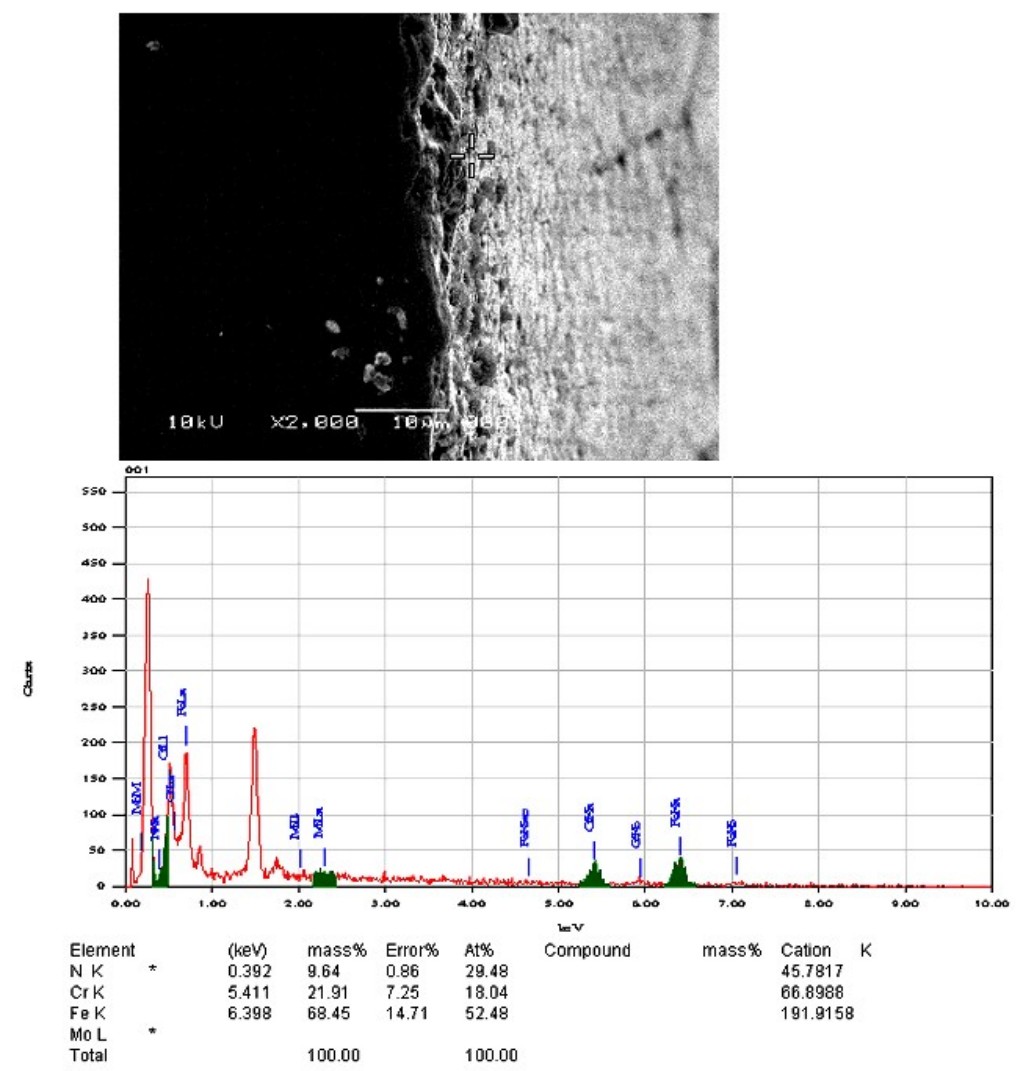

Gambar 5. Tampang lintang mikrograf SEM-EDAX dari cuplikan SS $316 \mathrm{~L}$ setelah nitridasi ion pada suhu nitridasi $500^{\circ} \mathrm{C}$, waktu nitridasi 3 jam dan tekanan gas nitrogen 1,6 mbar.

Gambar 6 menampilkan mikrograf SEM-EDAX dari cuplikan Ti-6Al-4V setelah nitridasi ion pada suhu nitridasi $500{ }^{\circ} \mathrm{C}$, waktu nitridasi 3 jam dan tekanan gas nitrogen 1,8 mbar. Hasil analisis komposisi kimia menunjukkan bahwa kandungan nitrogen pada permukaan cuplikan setelah proses nitridasi ion adalah $36,20 \%$ atom atau $14,73 \%$ massa. Berdasarkan diagram fase Ti-N dapat diperkiraan pada permukaan cuplikan tersebut akan terbentuk lapisan senyawa $\mathrm{TiN}$ dan $\mathrm{Ti}_{2} \mathrm{~N}$ yang mempunyai sifat keras atau mempunyai ketahanan aus yang baik. Untuk memastikan struktur fase senyawa nitrida titanium yang terbentuk digunakan teknik XRD.

\section{Pengamatan Struktur Fase Lapisan Senyawa}

Seperti telah disebutkan di atas, untuk mengetahui struktur fase lapisan nitrida yang terbentuk pada permukaan cuplikan, baik cuplikan SS 316L dan Ti-6Al-4V, dilakukan menggunakan teknik difraksi sinar-X (XRD). Hasil pengamatan XRD menggunakan sumber radiasi CuK $\alpha$ dengan $\lambda=1,54056 \AA$ pada cuplikan SS $316 \mathrm{~L}$ sesudah proses nitridasi ion pada suhu nitridasi $500^{\circ} \mathrm{C}$, waktu nitridasi 3 jam dan tekanan gas nitrogen 1,6 mbar ditampilkan pada Gambar 7; sedangkan Gambar 8 menampilkan pola difraksi cuplikan Ti-6Al-4V sesudah proses nitridasi ion pada suhu nitridasi $500^{\circ} \mathrm{C}$, waktu nitridasi 3 jam dan tekanan gas nitrogen 1,8 mbar.

Berdasarkan informasi sudut hamburan, intensitas dan jarak antar bidang pada Gambar 7, setelah dicocokan dengan data JCPDS (Joint Comittee Powder on Diffraction Standards), pola difraksi cuplikan SS 316L sesudah proses nitridasi ion menghasilkan puncak-puncak $\mathrm{FeN}(101), \operatorname{MoN}(211), \mathrm{Cr}_{2} \mathrm{~N}(300), \mathrm{Fe}_{4} \mathrm{~N}(300)$ dan $\mathrm{Fe}_{2} \mathrm{~N}(420) ; \quad$ masing-masing dengan jarak antar-bidang 2,05531 $\AA$, 1,78317 $\AA, 1,39906 \AA, 1,26510 \AA$, dan $1,19502 \AA$, pada sudut difraksi $(2 \theta) 44,022^{\circ}, 51,187^{\circ}, 66,814^{\circ}, 75,018^{\circ}$, dan $80,270^{\circ}$. Terbentuknya lapisan nitrida besi dengan struktur $\mathrm{FeN}, \mathrm{Fe}_{2} \mathrm{~N}$ dan $\mathrm{Fe}_{4} \mathrm{~N}$, juga lapisan nitrida lainnya dengan struktur $\mathrm{MoN}$ dan $\mathrm{Cr}_{2} \mathrm{~N}$ pada permukaan cuplikan SS 316L hasil nitridasi ion tersebut mempunyai sifat sangat keras atau mempunyai ketahanan aus yang sangat tinggi. 


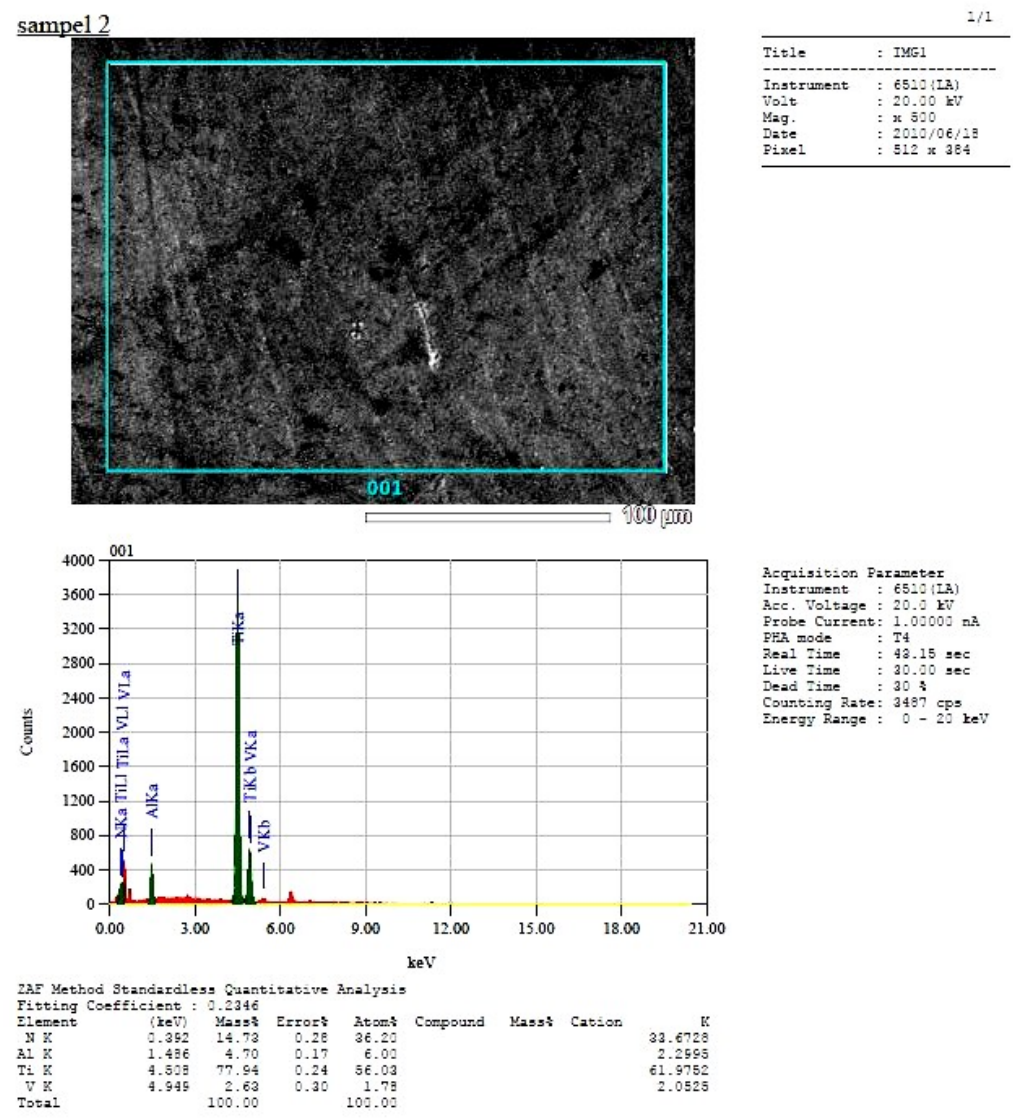

Gambar 6. Mikrograf SEM-EDAX dari cuplikan Ti-6Al-4V setelah nitridasi ion pada suhu nitridasi $500{ }^{\circ} \mathrm{C}$, waktu nitridasi 3 jam dan tekanan gas nitrogen 1,8 mbar.

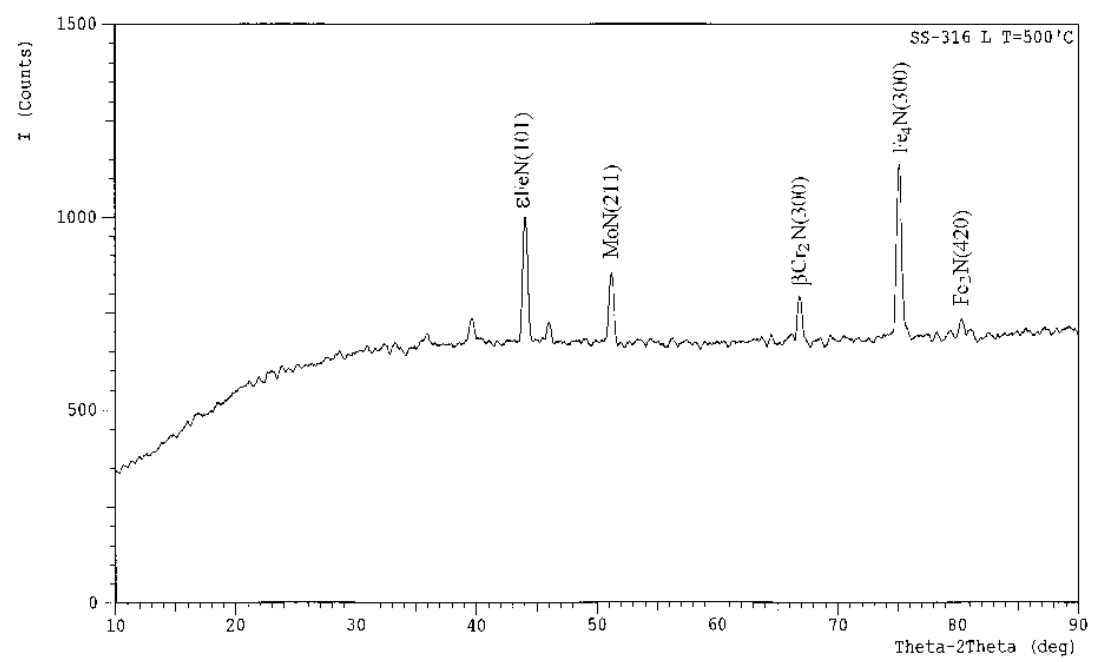

Gambar 7. Pola difraksi cuplikan SS $316 \mathrm{~L}$ setelah proses nitridasi ion pada suhu nitridasi $500{ }^{\circ} \mathrm{C}$, waktu nitridasi 3 jam dan tekanan gas nitrogen 1,6 mbar. 


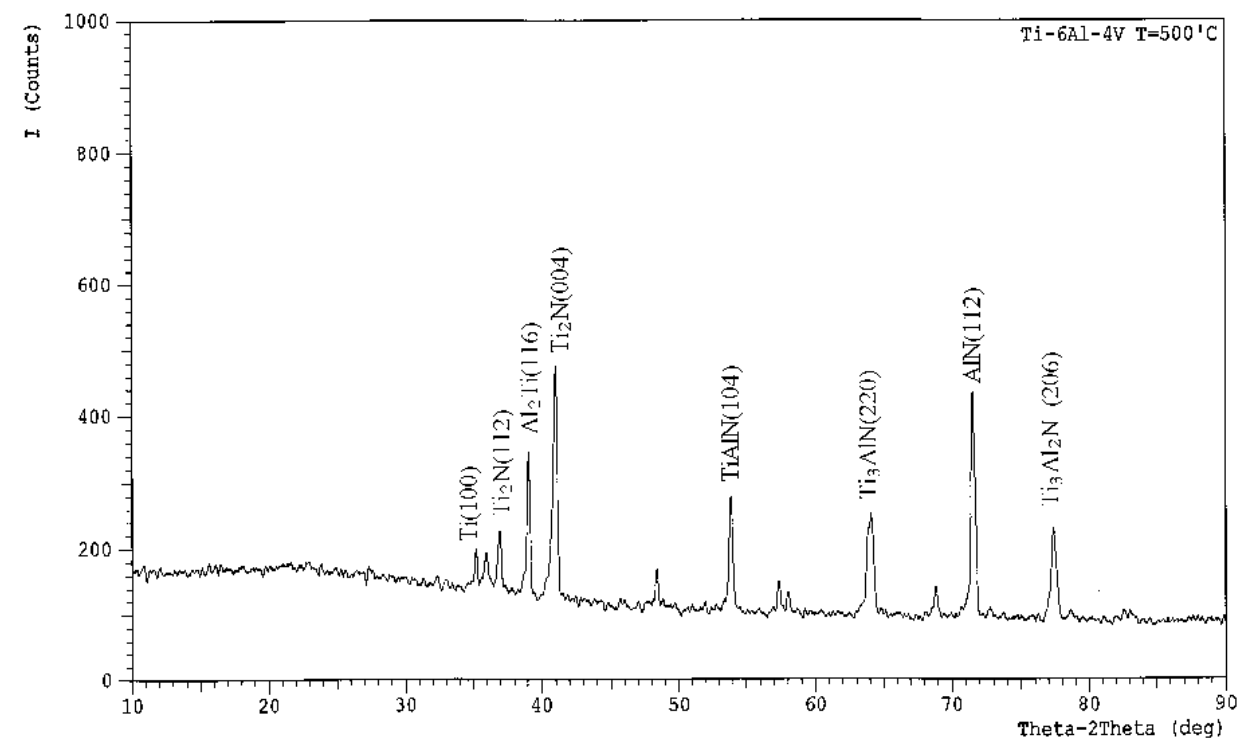

Gambar 8. Pola difraksi cuplikan Ti-6Al-4V setelah proses nitridasi ion pada suhu nitridasi $500{ }^{\circ} \mathrm{C}$, waktu nitridasi 3 jam dan tekanan gas nitrogen 1,8 mbar.

Pada Gambar 8 ditampilkan pola difraksi cuplikan Ti-6Al-4V setelah proses nitridasi ion pada suhu nitridasi $500{ }^{\circ} \mathrm{C}$, waktu nitridasi 3 jam dan tekanan gas nitrogen 1,8 mbar. Berdasarkan informasi sudut hamburan, intensitas dan jarak antar bidang pada Gambar 8, setelah dicocokan dengan data JCPDS (Joint Comittee Powder on Diffraction Standards), pola difraksi cuplikan Ti-6Al-4V sesudah proses nitridasi ion menghasilkan puncak-puncak Ti(100), $\mathrm{Ti}_{2} \mathrm{~N}(112), \mathrm{Al}_{2} \mathrm{Ti}(116), \mathrm{Ti}_{2} \mathrm{~N}(004)$, TiAIN(104), $\mathrm{Ti}_{3} \mathrm{AIN}(220), \operatorname{AIN}(112)$ dan $\mathrm{Ti}_{3} \mathrm{Al}_{2} \mathrm{~N}_{2}(206)$; masing-masing dengan jarak antar-bidang 2,49923 $\AA, 2,43437 \AA, 2,30601 \AA, 2,20165 \AA, 1,70193 \AA, 1,45119 \AA$, $1,31842 \AA$, dan $1,23279 \AA$, pada sudut difraksi $(2 \theta) 35,903^{\circ}, 36,894^{\circ}, 39,028^{\circ}, 40,959^{\circ}, 53,822^{\circ}, 64,120^{\circ}, 71,502^{\circ}$ dan $77,341^{\circ}$. Pembentukan lapisan nitrida titanium dengan struktur $\mathrm{Ti}_{2} \mathrm{~N}$, nitrida titanium aluminium dengan struktur TiAIN, $\mathrm{Ti}_{3} \mathrm{AIN}$ dan $\mathrm{Ti}_{3} \mathrm{Al}_{2} \mathrm{~N}_{2}$ serta nitrida aluminium dengan struktur AIN pada permukaan cuplikan Ti-6Al$4 \mathrm{~V}$ hasil nitridasi ion tersebut meningkatkan nilai kekerasan atau mempunyai ketahanan aus sangat tinggi.

\section{Karakterisasi Ketahanan Korosi Cuplikan}

Dalam penelitian ini juga dilakukan uji ketahanan korosi cuplikan SS 316L dan Ti-6Al-4V, sebelum dan sesudah proses nitridasi ion menggunakan larutan Hanks yang disimulasikan mirip dengan cairan tubuh manusia ${ }^{(1)}$. Larutan Hanks dibuat di laboratorium dengan bahan-bahan kimia yang terdiri dari: $\mathrm{NaCl} 8,0 \mathrm{~g} / \mathrm{l}, \mathrm{CaCl}_{2}$ 0,14g/l, $\mathrm{KCl} 0,4 \mathrm{~g} / \mathrm{l}, \mathrm{NaHCO}_{3}$ 0,35g/l, glukosa 1,0g/l, $\mathrm{NaH}_{2} \mathrm{PO}_{4}$ 0,1 g/l, $\mathrm{MgCl}_{2} \cdot 6 \mathrm{H}_{2} \mathrm{O}$ 0,1g/l, $\mathrm{Na}_{2} \mathrm{HPO}_{4} \cdot 2 \mathrm{H}_{2} \mathrm{O}$ 0,06g/l, $\mathrm{MgSO}_{4} .7 \mathrm{H}_{2} \mathrm{O}$ 0,06g/l. Pengukuran ketahanan korosi cuplikan dilakukan dengan menggunakan potensiostat PGS-201T dengan bahan pelarutan berupa larutan Hanks tersebut di atas. Ketepatan penentuan nilai intensitas arus korosi $\left(I_{\text {kor }}\right)$ sangat diperlukan, karena $I_{\text {kor }}$ berbanding langsung dengan besarnya laju korosi. Pada Gambar 9 ditampilkan kurva potensial vs log intensitas arus korosi cuplikan: (a) SS 316 Ltandar dan (b) Ti-6Al-4V standar, sebelum proses nitridasi ion pada uji korosi dalam larutan Hanks. Arus korosi cuplikan SS 316L standar sebelum nitridasi ion adalah $410,38 \mu \mathrm{A} / \mathrm{cm}^{2}$, dan arus korosi cuplikan Ti-6Al-4V sebelum nitridasi ion adalah $242,49 \mu \mathrm{A} / \mathrm{cm}^{2}$. Pada Gambar 10 ditampilkan kurva potensial vs log intensitas arus korosi cuplikan: (a) SS $316 \mathrm{~L}$ setelah nitridasi ion untuk suhu nitridasi $450^{\circ} \mathrm{C}$, waktu nitridasi 3 jam dan tekanan gas nitrogen 1,6 mbar, (b) Ti6Al-4V setelah nitridasi ion dengan suhu nitridasi $450^{\circ} \mathrm{C}$, waktu nitridasi 3 jam dan tekanan gas nitrogen 1,8 mbar. Berdasarkan pada Gambar 10 tersebut dapat diketahui bahwa arus korosi cuplikan SS 316L mengalami penurunan cukup besar setelah proses nitridasi ion yaitu $318,02 \mu \mathrm{A} / \mathrm{cm}^{2}$, sedangkan arus korosi untuk cuplikan Ti-6Al-4V adalah $157,68 \mu \mathrm{A} / \mathrm{cm}^{2}$. Arus korosi ini menentukan sifat permukaan bahan, untuk bahan yang lebih 
tahan terhadap korosi maka arus korosinya kecil, yang berarti bahwa cuplikan hasil nitridasi ion pada suhu nitridasi $450{ }^{\circ} \mathrm{C}$ tersebut memiliki ketahanan korosi yang sangat baik.

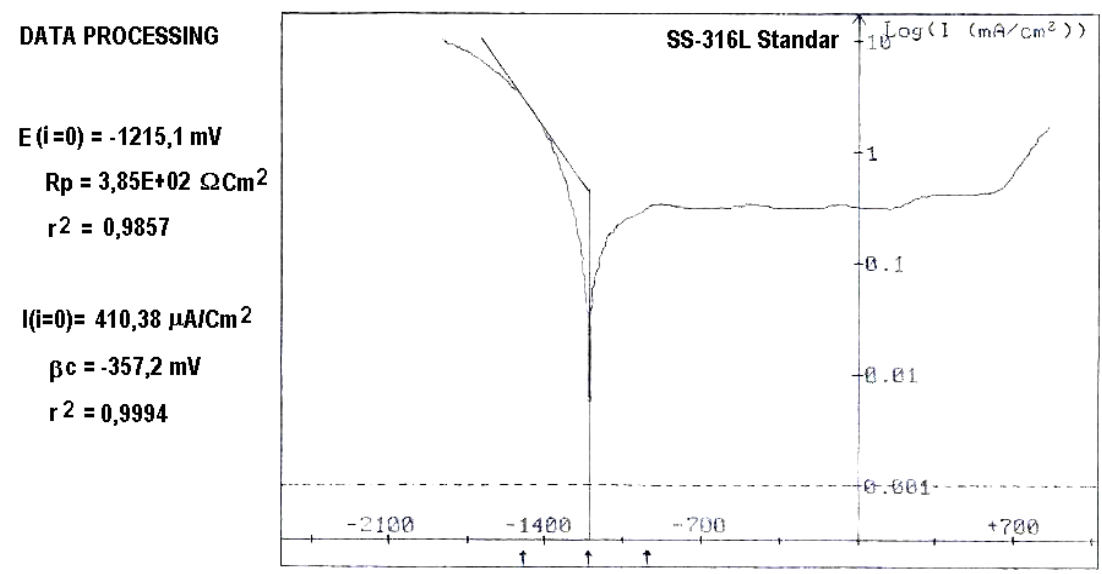

(a)

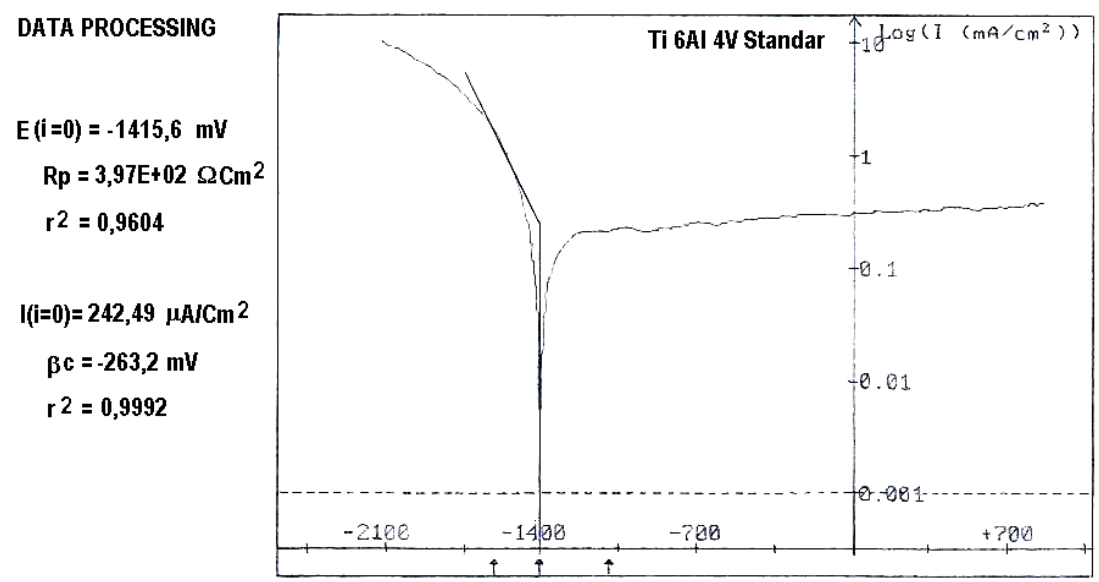

(b)

Gambar 9. Kurva potensial vs log intensitas arus korosi cuplikan: (a) SS 316L standar dan (b) Ti-6Al-4V standar, sebelum proses nitridasi ion pada uji korosi dalam larutan Hanks.

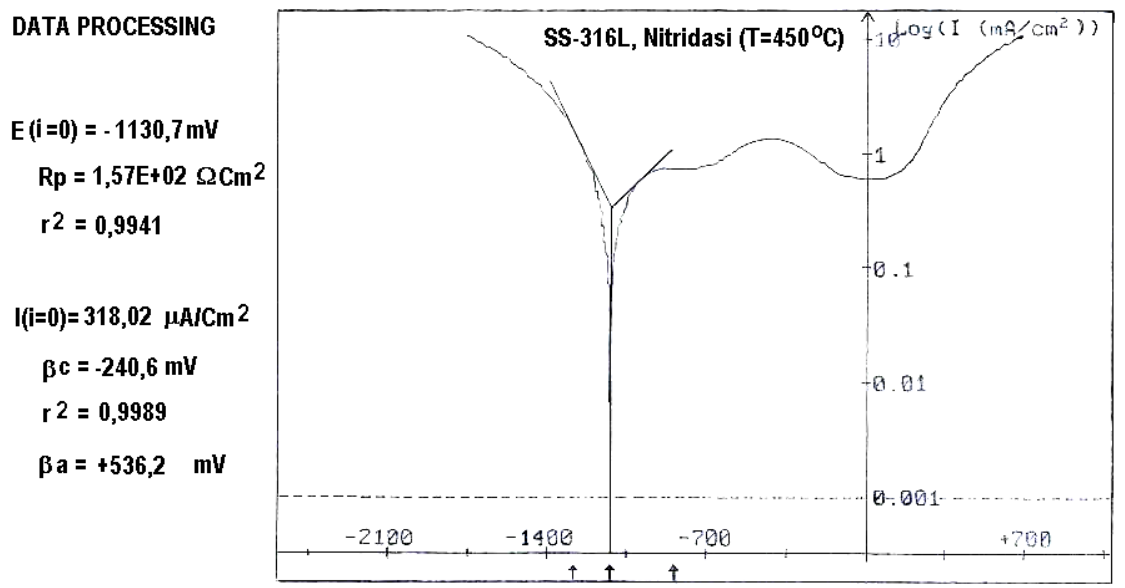


(a)

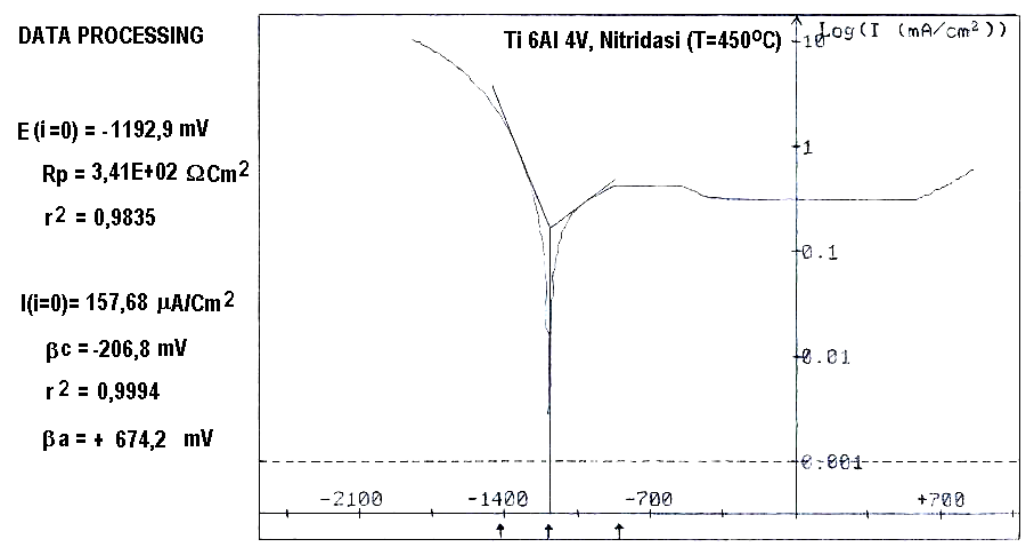

(b)

Gambar 10. Kurva potensial vs log intensitas arus korosi cuplikan: (a) SS $316 \mathrm{~L}$ hasil nitridasi ion untuk suhu nitridasi $450{ }^{\circ} \mathrm{C}$, waktu nitridasi 3 jam dan tekanan gas nitrogen 1,6 mbar, (b) Ti-6Al-4V hasil nitridasi ion untuk suhu nitridasi $450^{\circ} \mathrm{C}$, waktu nitridasi 3 jam dan tekanan gas nitrogen 1,8 mbar, pada uji korosi dalam larutan Hanks.

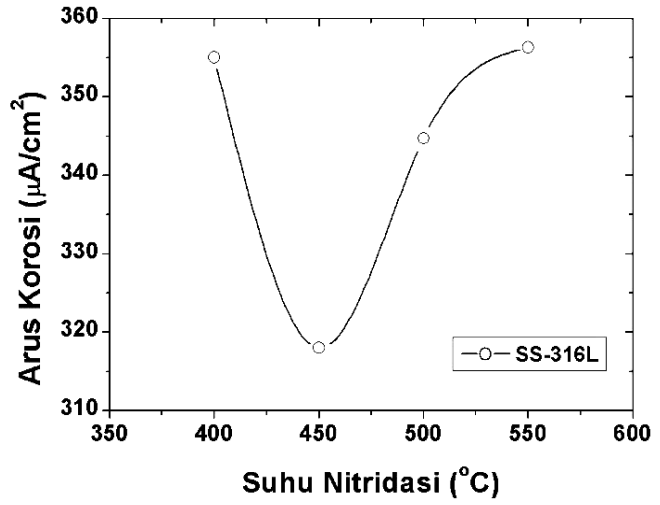

Gambar 11. Grafik hubungan arus korosi dan suhu nitridasi dari cuplikan SS 316L untuk variasi suhu nitridasi, pada waktu nitridasi 3 jam dan tekan gas nitrogen 1,6 mbar.

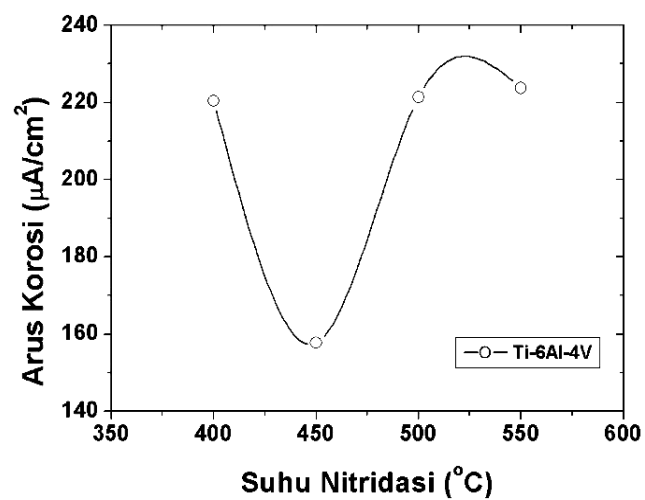

Gambar 12. Grafik hubungan arus korosi dan suhu nitridasi dari cuplikan Ti-6Al-4V untuk variasi suhu nitridasi, pada waktu nitridasi 3 jam dan tekan gas nitrogen 1,8 mbar. 
Gambar 11 menampilkan grafik hubungan arus korosi dan suhu nitridasi dari cuplikan SS 316L untuk variasi suhu nitridasi $400-550{ }^{\circ} \mathrm{C}$, pada waktu nitridasi 3 jam dan tekanan gas nitrogen 1,6 mbar; sedangkan Gambar 12 menampilkan grafik hubungan arus korosi dan suhu nitridasi dari cuplikan Ti-6Al-4V untuk variasi suhu nitridasi $400-550^{\circ} \mathrm{C}$, pada waktu nitridasi 3 jam dan tekanan gas nitrogen 1,8 mbar. Berdasarkan Gambar 11 dan 12 tersebut, ketahanan korosi optimum diperoleh pada suhu nitridasi $450{ }^{\circ} \mathrm{C}$, sedangkan pada suhu nitridasi di atas $500{ }^{\circ} \mathrm{C}$ terjadi degradasi ketahanan korosi. Degradasi ini, khususnya pada stainless steel $316 \mathrm{~L}$, disebabkan karena pembentukan nitrida khrom selama perlakuan permukaan yang mengurangi kandungan khrom bebas yang tersedia untuk pembentukan lapisan permukaan protektif. Pada suhu nitridasi yang rendah, yaitu pada suhu $450{ }^{\circ} \mathrm{C}$ dapat membentuk suatu lapisan permukaan termodifikasi yang terdiri dari fase metastabil yang diketahui sebagai fase superjenuh atau fase-S, yang memiliki kekerasan tinggi dan ketahanan korosi sangat baik ${ }^{(13-15)}$. Fase-S ini adalah larutan padat nitrogen superjenuh, dimana nitrogen tetap dalam larutan padat superjenuh tanpa mengurangi khrom dari struktur austenitik oleh pengendapan nitrida khrom. Borgioali dkk. ${ }^{(13)}$ dan Fernandes dkk. ${ }^{(16)}$ juga mendapatkan ketahanan korosi optimum pada suhu nitridasi $450{ }^{\circ} \mathrm{C}$, dimana pada suhu ini terbentuk suatu lapisan homogen dan kontinyu yang mengandung fase-S.

\section{KESIMPULAN} berikut.

Berdasarkan hasil dan pembahasan tersebut di atas dapat diambil beberapa kesimpulan penting sebagai

1. Berdasarkan hasil karakterisasi kekerasan cuplikan diperoleh bahwa nilai kekerasan optimum dari cuplikan SS $316 \mathrm{~L}$ diperoleh pada tekanan gas nitrogen 1,6 mbar, suhu nitridasi ion $500{ }^{\circ} \mathrm{C}$ dan waktu nitridasi ion 3 jam, yang meningkat sekitar $136 \%$ terhadap kekerasan standar. Pada cuplikan Ti-6Al-4V, kekerasan optimumnya diperoleh pada tekanan gas nitrogen 1,8 mbar, suhu nitridasi ion $500{ }^{\circ} \mathrm{C}$ dan waktu nitridasi ion 3 jam; nilai kekerasan tersebut meningkat sebesar sekitar $240 \%$ terhadap kekerasan standar. Uji keausan diketahui bahwa peningkatan ketahanan aus optimum mencapai $600 \%$ untuk cuplikan SS 316L, sedangkan pada cuplikan Ti-6Al-4V terjadi peningkatan sekitar 375\% jika dibandingkan dengan cuplikan standar.

2. Pengamatan struktur-mikro dan komposisi unsur nitrogen dari cuplikan SS $316 \mathrm{~L}$ dengan kekerasan optimum tersebut diketahui bahwa pada permukaan cuplikan mengandung unsur nitrogen 18,79\% atom yang membentuk lapisan senyawa nitrida besi dengan struktur fase $\mathrm{FeN}, \mathrm{Fe}_{2} \mathrm{~N}$ dan $\mathrm{Fe}_{4} \mathrm{~N}$. Sedangkan untuk cuplikan Ti-6Al-4V pada kekerasan optimum diketahui bahwa pada permukaan cuplikan mengandung nitrogen $36,20 \%$ atom yang membentuk lapisan senyawa nitrida titanium $\mathrm{Ti}_{2} \mathrm{~N}, \mathrm{TiAIN}, \mathrm{Ti}_{3} \mathrm{AIN}$ dan $\mathrm{Ti}_{3} \mathrm{Al}_{2} \mathrm{~N}_{2}$. Lapisan senyawa nitrida metal tersebut mempunyai sifat sangat keras atau mempunyai ketahanan aus yang tinggi.

3. Ketahanan korosi optimum untuk cuplikan SS $316 \mathrm{~L}$ dan Ti-6Al-4V diperoleh pada suhu nitridasi $450{ }^{\circ} \mathrm{C}$, dimana pada kondisi ini telah terbentuk fase-S yang adalah larutan padat nitrogen superjenuh, yang mempunyai sifat ketahanan aus yang tinggi dan ketahanan korosi sangat baik.

\section{UCAPAN TERIMA KASIH}

Penelitian ini sepenuhnya dibiayai dari Program Insentif Peningkatan Kemampuan Peneliti dan Perekayasa Tahun 2010, Kantor Kementerian Riset dan Teknologi. Pada kesempatan ini penulis mengucapkan terima kasih yang sebesar-besarnya kepada BATAN dan Kementerian Riset dan Teknologi yang telah membiayai kegiatan yang kami lakukan, sehingga penelitian ini dapat dilaksanakan dengan baik.

\section{DAFTAR PUSTAKA}

1. U.K. MUDALI, T.M. SRIDHAR and B. RAJ, Corrosion of bio implants, Sadhana Vol. 28, Parts 3 \& 4, June/August (2003), 601-637 
2. D.C. HANSEN, Metal Corrosion in the Human Body: The Ultimate Bio-Corrosion Scenario, The Electrochemical Society Interface, (2008) 31-34

3. R.B. HEIMANN, "Modern bioceramic materials: design, testing and clinical application", Engineering Mineralogy of Ceramic Materials, Proceedings of the International School Earth and Planetary Sciences, Siena (2001)

4. M. CAMERON, Ageing Population and Technological Progress Combine to Drive European Orthopedic Braces and Supports Market, Technician News, (2004)

5. P.I. JOHN, Plasma Sciences and the Creation of Wealth, Institute for Plasma Research Village Bhat, Gandhinagar, Tata McGraw-Hill Publishing Company Limited, New Delhi, (2005)

6. A. PRAEMER, S. FURNER, and D.P. PRICE, Musculoskeletal Conditions in the United States, American Academy of Orthopedic Surgeons, (1999)

7. Bharat Book Bureau, Orthopedic Implants Forecasts for 2012 \& 2017, Business Market Reports, (2008)

8. A. CHOUBEY, B. BASU, and R. BALASUBRAMANIAM, Trends Biomater. Artif. Organs, Vol. 18(2), January (2005), 141-47

9. A. CHOUBEY, B. BASU, and R. BALASUBRAMANIAM, Intermetallics Volume 12, Issue 6 (2004) 679-682

10. SUDJATMOKO, "Kajian Pemanfaatan Biomaterial Austenitik 316L Dalam Bidang Orthopedik", Prosiding Pertemuan dan Presentasi Ilmiah Teknologi Akselerator dan Aplikasinya, Volume 10, Oktober (2008), 110 117

11. B. RODRIGUEZ, A. ROMERO, O. SOTO, and O. de VARORNA, Biomaterials for orthopedics, Applications of Engineering Mechanics in Medicine, GED - University of Puerto Rico, Mayaguez, May (2004) 1-26

12. A.M. de OLIVEIRA, R.M. MUNOZ RIOFANO, L.C. CASTELETTI, G.F. TREMILIOSI, C.A.S. BENTO, Effect of the temperature of plasma nitriding in AISI 316L austenitic stainless steel, Revista Brasileira de Aplicacoes de Vacuo, Vol. 22, №. 2, (2003) 63-66

13. F. BORGIOLI, A. FOSSATI, E. GALVANETTO, T. BACCI, Surface \& Coatings Technology 200 (2005) 24742480

14. M. DROUET, J.C. STINVILLE, P. VILLECHAISE, J.P. RIVIERE, and C. TEMPLIER, The European Physical Journal Applied Physics 43 (2008) 349-351

15. L.C. GONTIJO, R. MACHADO, L.C. CASTELETTI, S.E. KURI, and P.A.P. NASCENTE, Materials Science Forum, Volume 638-642 (2010) 775-780

16. F.A.P. FERNANDES, S.C. HECK, R.G. PEREIRA, A. LOMBARDI-NETO, G.E. TOTTEN, L.C. CASTELETTI, Journal of Achievements in Materials and Manufacturing Engineering, Volume 40, Issue 2, (2010) 175-179 